\title{
The Investigations on Pulp and Paper Production with Modified Kraft Pulping Method from Canola (Brassica napus L.) Stalks
}

\author{
Mehmet AKGÜL ${ }^{1}$, Ilhan ERDÖNMEZ2 ${ }^{2}$, Mustafa ÇİÇEKLER ${ }^{2 *}$, Ahmet TUTUŞ² \\ ${ }^{1}$ Karamanoglu Mehmetbey University, TURKEY \\ ${ }^{2}$ Kahramanmaras Sutcu Imam University, Forest Industry Engineering, Kahramanmaras, TURKEY \\ *Corresponding author: mcicekler87@gmail.com
}

Received Date: 16.03 .2018

Accepted Date: 03.12.2018

\section{Abstract}

Aim of study: This study was carried out to evaluate canola (Brassica napus L.) stalks as an alternative raw material for pulp and paper production.

Area of study: This work was carried out in Kahramanmaraş Sütçü Imam University, Faculty of Forestry, Pulp and Paper Production Laboratory.

Material and Methods: Before pulping procedure, the chemical components of the canola stalks were investigated. The holocellulose, alpha cellulose, lignin, and ash contents and $\mathrm{NaOH}(1 \%)$ and cold-hot water solubilities were determined. Modified kraft cooking method was used for pulping from canola stalk by using sodium borohydride $\left(\mathrm{NaBH}_{4}\right)$. Sulfidity charge; $26,28,30 \%$, and $\mathrm{NaBH}_{4}$ charge; $0,0.1,0.3,0.5 \%$ were changed while keeping constant temperature $\left(150{ }^{\circ} \mathrm{C}\right)$, time $(120 \mathrm{~min})$ and alkali charge $(20 \%)$. For determination of the optimum pulping condition, 12 cooking experiments were performed to canola stalks. In addition, the physical and optical properties of the papers produced from the obtained pulps were also determined.

Main results: The holocellulose (72.10\%) and lignin (13.15\%) contents of the canola stalks were found to be similar with hardwoods. The optimum cooking condition was determined as $20 \%$ active alkali, $28 \%$ sulfidity and $0.5 \% \mathrm{NaBH}_{4}$ charges (as $\mathrm{NaOH}$ ) and the total pulp yield were obtained about $44.7 \%$ in this condition. Besides, the addition of $\mathrm{NaBH}_{4}$ increased pulp yield by $24.1 \%$ and decreased kappa number by $9.7 \%$.

Research highlights: It was concluded that obtained results demonstrate the suitability of canola stalk for pulp and paper production and $\mathrm{NaBH}_{4}$ is an effective cooking additive for the pulp yield.

Keywords: Brassica napus L., canola stalk, $\mathrm{NaBH}_{4}$, Kraft pulping

\section{Kanola Saplarından (Brassica napus L.) Modifiye Kraft Yöntemi ile} Kağıt Hamuru ve Kağıt Üretimi Üzerine Araştırmalar

\section{$\ddot{O} \mathbf{z}$}

Çalışmanın amact: $\mathrm{Bu}$ çalışma, kanola (Brassica napus L.) saplarının kağıt hamuru ve kağıt üretiminde alternatif bir hammadde olarak değerlendirilmesini amaçlamıştır.

Çalışmanın alanı: Bu çalışma Kahramanmaraş Sütçü İmam Üniversitesi, Orman Fakültesi, Kağıt Hamuru ve Kağıt Üretim Laboratuvarı'nda yürütülmüștür.

Materyal ve Yöntem: Kağıt hamuru üretimine geçilmeden önce kanola saplarının kimyasal içeriği araştırılmıştır. Holoselüloz, alfa selüloz, lignin ve kül içerikleri ile $\mathrm{NaOH}$ (\%1), soğuk ve sıcak su çözünürlükleri belirlenmiştir. Kanola saplarından kağıt hamuru üretimi için $\mathrm{NaBH}_{4}$ ilaveli modifiye kraft yöntemi kullanılmıştır. Sülfidite $\% 26,28$ ve $30, \mathrm{NaBH}_{4} ; \% 0,0.1,0.3$, ve 0.5 oranlarında değiş̧tirilirken aktif alkali oranı $\% 20$ olarak sabit tutulmuştur. Optimum koşulu belirlemek için 12 farklı koşulda pişirme işlemi yapılmıştır. Ayrıca elde edilen kağıt hamurlarından üretilen kağıtların fiziksel ve optik özellikleri de belirlenmiştir.

Sonuçlar: Kanola saplarının holoselüloz (\%72.10) ve lignin (\%13.15) içeriği yapraklı ağaç odunları ile benzer oranlarda bulunmuştur. Optimum pişirme, $\% 20$ aktif alkali, \%28 sülfidite ve $\% 0.5 \mathrm{NaBH}_{4}$ oranlarının kullanıldığ koşulda elde edilmiş ve bu koşulda kağıt hamuru toplam verimi \%44.7 olarak bulunmuşstur. Aynı zamanda $\mathrm{NaBH}_{4}$ ilavesi ile toplam verim \%24.1 oranında artarken kappa numarası \%9.7 oranında azalmıştır.

Araştırma Vurgulart: Elde edilen sonuçlar, kanola saplarının kağıt hamuru ve kağı̆ üretimi için uygunluğunu ve $\mathrm{NaBH}_{4}$ 'ün hamur verimliliği için etkili bir pişirme katkı maddesi olduğunu ortaya koymuştur.

Anahtar kelimeler: Brassica napus L., kanola sapları, $\mathrm{NaBH}_{4}, \mathrm{Kraft}$ pişirmesi 


\section{Introduction}

Cellulose is one of the most abundant biopolymers in the world. It is found in wood, cotton and other lignocellulosic materials such as agricultural wastes and annual plants (Moon, Martini, Nairn, Simonsenf \& Youngblood, 2011; Gunduz, Asik, Aydemir \& Kilic, 2015). Wood raw material is generally used as a cellulose source in pulp and paper production. However, difficulties have arisen in the procurement of wood raw materials due to the laws on the protection of forest resources. Difficulties of supplying sources for pulp and paper production have given rise papermakers to seek new sources. Some researchers have been done to discover new raw materials. As a result of these investigations, it has been reported that annual plants and agricultural wastes can be evaluated in pulp and paper productions as substitute to wood. The use of annual plants for pulp and paper production has begun in the $19^{\text {th }}$ century. Paper consumption has increased with population growth and the advancement of technology and therefore the use of annual plants in pulp and paper production also increased rapidly after the Second World War (Eroglu and Deniz, 1987; Rowell, Young \& Rowell, 1997; Tutus 2000; Gencer, Eroglu \& Deniz, 2005; Akgul, 2007; Tutus and Cicekler, 2016).

The evaluation of agricultural wastes in pulp and paper industry provides both economic and environmental benefits. The manufacturing of pulps from non-wood materials has increased and nowadays some non-wood fiber sources are commercially handled to produce pulp and paper in some countries such as Turkey, Africa, India and China. In 2016, there are approximately 82 million tons of agricultural wastes in Turkey (Faostat, 2018). Wheat and rice stalks are main agricultural wastes used in pulp and paper production. In addition to these, sorghum, jute and hemp stalks are also used as raw materials in Turkey and world (Rousu, Rousis \& Anttila, 2002; Ashori, 2006; SKSV, 2018). Plentiful studies have also been carried out on new raw material as a fiber source in pulp and paper industry (Sarwar, Nasima \& Khalidul, 2006; Shatalov and Pereira, 2006; Tran, 2006; Wanrosli, Zainuddin, Lawb \& Asro, 2007; Tutus,
Cicekler, Ozdemir \& Altas, 2014; Tutus, Kazaskeroglu \& Cicekler, 2015;).

Canola (Brassica napus L.) is one of the most important industrial plants in many countries of the world. With the begin of the Second World War in 1940s, canola production increased and nowadays it is the oil seed plant with the fastest growth rate (Guler, Kara \& Dok, 2005). Annual canola production in the world is around 170 million tons. It was approximately 12.000 tons of canola production in Turkey. After the canola seeds are collected, approximately $20 \%$ of the stalks remain in the field (Banuelos, Bryla \& Cook, 2002; Enayati, Hamzeh, Mirshokraie \& Molaii, 2009; Tiras, 2009). According to this calculation, approximately 34 million tonnes of canola stalks per year remain in fields. It was concluded that this amount demonstrates the suitability of canola stalk in numerous products.

The kraft method is the most used method for obtaining pulp suitable for papermaking. Increasing the pulp yield in pulping is very important to the pulp and paper industries. Modifying kraft cooking, such as with sodium borohydride $\left(\mathrm{NaBH}_{4}\right)$ addition, is one way to increase pulp yield (Courchene, 1998; Tutus and Eroglu, 2003; Tutus and Eroglu, 2004; Tutus and Usta 2004; Hafizoglu and Deniz, 2007; Istek and Gunteki, 2009).

In many countries, especially in Turkey, canola stalks are burned for heating or energy production. There is little information on the utilization of these raw materials in paper industry. The aim of this study was to evaluate canola stalks for pulp and paper production, using Kraft and Kraft- $\mathrm{NaBH}_{4}$ cooking methods.

\section{Material and Method \\ Material}

Canola stalks were taken from Karacabey Agricultural Management Directorate (Bursa). Chemicals used in this study were supplied by Merck and Sigma. Chemical, optical and physical properties of the canola pulps and raw material preparation were investigated according to relevant standards. 


\section{Chemical Analysis}

The canola stalks were cut into the length of 2-4 cm, and grained to 60 mesh fractions in a willey mill. Prepared materials were used to investigate its chemical components according to standards given in below;

Holocellulose content: Wise chloride method (Wise and Murphy, 1962).

Lignin content: TAPPI T222 om-11 09

Alpha cellulose content: TAPPI T203 cm-

Ash content: TAPPI T211 om-02

Alcohol-Benzene solubility: TAPPI T204 cm-07

Cold-Hot Water solubility: TAPPI T207 om- 88

$1 \% \mathrm{NaOH}$ solubility: TAPPI T212 om- 12

Three replicates were performed for each treatment and mean values were used.

\section{Pulp and Paper Production}

Total of 12 cooking experiments (3 control and $9 \mathrm{NaBH}_{4}$ added) were performed to determine optimum pulping conditions and effects of $\mathrm{NaBH}_{4}$ on pulp properties. Sulfidity charge; $26,28,30 \%$, and $\mathrm{NaBH}_{4}$ charge; $0,0.1,0.3,0.5 \%$ were changed while keeping constant temperature $\left(150^{\circ} \mathrm{C}\right)$, time $(120 \mathrm{~min})$ and alkali charge $(20 \%)$. The pulping conditions performed canola stalks were given in Table 1.

Table 1. Pulping conditions for canola stalks

\begin{tabular}{lcc}
\hline Pulping conditions & Unit & Value \\
\hline Active Alkali charge & $\%$ (as & 20 \\
& $\mathrm{NaOH})$ & \\
Sulfidity charge & $\%($ as & $26,28,30$ \\
& $\mathrm{NaOH})$ \\
& $\%(\mathrm{as}$ & $0,0.1,0.3,0.5$ \\
$\mathrm{NaBH}_{4}$ charge & $\mathrm{NaOH})$ \\
\multicolumn{4}{c}{ Cooking temperature } & ${ }^{\circ} \mathrm{C}$ & 150 \\
Cooking time & $\mathrm{Min}$ & 120 \\
Cooking liquor/stalk & $\mathrm{L} / \mathrm{kg}$ & $5 / 1$ \\
\hline
\end{tabular}

The cooking trials were carried out in rotary digester and governed with digital temperature control system and electrically heated. Obtained pulps were washed with tap water to remove black liquor and disintegrated. Then, the pulps were screened on a $0.15 \mathrm{~mm}$ with a Somerville Screen. Viscosity and kappa values of all pulps were also determined according to TAPPI T230 om-08 and TAPPI T236 om-13 standards, respectively.

The pulps were beaten to $50 \pm 5$ o $\mathrm{SR}$ (Schopper-Riegler) freeness level in a hollander beater and ten test papers with grammages of 70 g.m $\mathrm{m}^{-2}$ were produced with using a Rapid-Kothen sheet former according to ISO 5269-2. The physical and optical properties of the papers were also determined according to relevant standards given in below; 06

Breaking length $(\mathrm{km})$ : TAPPI T494 om-

Burst index $\left(\mathrm{kPa} \cdot \mathrm{m}^{2} \cdot \mathrm{g}^{-1}\right)$ : TAPPI T403 om-15

Tear index $\left(\mathrm{mN} \cdot \mathrm{m}^{2} \cdot \mathrm{g}^{-1}\right)$ : TAPPI T414 om88

Brightness (\% ISO): ISO 2470-1.

\section{Statistical Analysis}

Statistical analysis of the obtained data was performed with the SPSS statistical package. Data of chemical, physical and optical properties of the pulp were analyzed using a computerized statistical program to determine variance, and by applying the Duncan test at a $\mathrm{P} \leq 0.05$ confidence level.

\section{Results and Discussion Chemical Components of Canola Stalks}

The chemical components of canola stalks were presented in Table 2 with those of some other annual plants. 
Table 2. Chemical components of canola stalks and some annual plants

\begin{tabular}{|c|c|c|c|c|c|c|c|}
\hline Chemical Components & 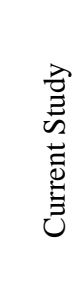 & 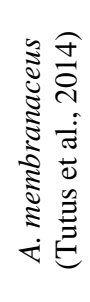 & 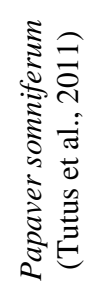 & 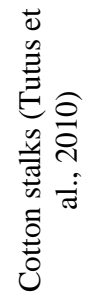 & 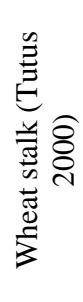 & 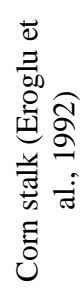 & 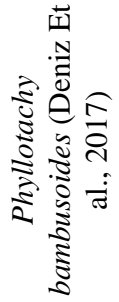 \\
\hline Holocellulose (\%) & 72.10 & 77 & 80 & 76 & 77 & 65 & 70.5 \\
\hline Alpha cellulose (\%) & 42.55 & 50 & 52 & 40 & 40 & 36 & 43.3 \\
\hline Lignin $(\%)$ & 13.15 & 24 & 19 & 18 & 18 & 17 & 24.5 \\
\hline Ash (\%) & 8.20 & 5.50 & 4.70 & 2.50 & 7.10 & 7.50 & 1.35 \\
\hline Extractives (\%) & 8.50 & 5.60 & - & 6.10 & 5.50 & 9.50 & 3.94 \\
\hline$\% 1 \mathrm{NaOH}(\%)$ & 40.4 & 29.4 & 30.3 & 30.9 & 40.9 & 47.1 & 25.1 \\
\hline Hot water (\%) & 16.4 & 8.40 & 10.4 & 14.2 & 12.2 & 14.8 & 6.47 \\
\hline Cold water $(\%)$ & 13.6 & 7.20 & 5.10 & 11.7 & 7.65 & - & - \\
\hline
\end{tabular}

According to Table 2, canola stalks contain $72.10 \%$ holocellulose, $42.55 \%$ alpha cellulose, $13.15 \%$ lignin and $8.2 \%$ ash. The main components such as holocellulose and lignin of the canola stalks were comparable with previous studies (Eroglu, usta \& Kirc1 1992; Eroglu and Deniz, 1998; Tutus, 2000; Tutus, Ezici \& Ates, 2010; Tutus et al., 2011; Tutus et al., 2014; Kiaei et al., 2014). The holocellulose content of canola stalks were found to be lower than other annual plants due to lower hemicellulose content (Tutus and Cicekler, 2016). While the holocellulose content of canola stalks was similar with that of softwood and hardwood (Kirci, 2006), the lignin content was found to be lower. Another notable property of canola stalks is $1 \% \mathrm{NaOH}$ solubility. As a result of alkalisoluble matters and low molecular weight carbohydrates, the $\mathrm{NaOH}(1 \%)$ solubility is higher (Tutus and Eroglu 2003). This solubility indicates fiber degradation during cooking trials (Zawawi, Mohd, Angzzas, Halizah \& Ashuvila, 2014). In addition, substance soluble in tannins, resins, water, polyphenols, and fragments of lignin and hemicelluloses can leach into alkaline solutions (Potucek, Gurung \& Hajkova,
2014). In a study in which the chemical components of canola were determined, ash, lignin, alpha cellulose, and holocellulose contents were found as $8.2 \%, 17.3 \%, 42 \%$, and $73.6 \%$, respectively (Enayati et al., 2009). According to these results, canola stalks were consistent with literature (Ekhtera, Azadfallah, Bahramin \& Rovshandeh, 2009; Enayati et al., 2009; Mohammad, Enayati, Hamzeh \& Roustaei, 2010; Hosseinpour and Latibati, 2012).

\section{Pulp and Paper Properties}

Yields, viscosities and kappa numbers, optical and physical properties of the pulps obtained from canola stalks were given in Table 3.

According to Table 3, the best applicable charges were determined as $28 \%, 20 \%$, and $0.5 \%$ for sulfidity, active alkali, and $\mathrm{NaBH}_{4}$, respectively $\left(11^{\text {th }}\right.$ trial). The total yield and kappa number of the pulps obtained with $11^{\text {th }}$ trial were found as $44.69 \%$ and 33.82 , respectively. It is clearly seen that $\mathrm{NaBH}_{4}$ has significant effect on pulp yield when compared with $2^{\text {nd }}$ trial (Fig. 1). 
Table 3. Yields, kappa numbers, viscosities, physical and optical properties of canola pulps

\begin{tabular}{|c|c|c|c|c|c|}
\hline C. No & $\begin{array}{c}\text { Active alkali } \\
(\%)\end{array}$ & Sulfidity (\%) & $\begin{array}{c}\mathrm{NaBH}_{4} \\
(\%)\end{array}$ & $\begin{array}{c}\text { Total yield } \\
(\%)\end{array}$ & $\begin{array}{l}\text { Kappa } \\
\text { No }\end{array}$ \\
\hline 1 & 20 & 26 & 0 & 34.17 & 42.10 \\
\hline 2 & 20 & 28 & 0 & 36.01 & 37.47 \\
\hline 3 & 20 & 30 & 0 & 40.88 & 39.72 \\
\hline 4 & 20 & 26 & 0.1 & 41.62 & 40.06 \\
\hline 5 & 20 & 28 & 0.1 & 34.46 & 33.79 \\
\hline 6 & 20 & 30 & 0.1 & 38.48 & 34.91 \\
\hline 7 & 20 & 26 & 0.3 & 36.84 & 47.86 \\
\hline 8 & 20 & 28 & 0.3 & 36.59 & 33.95 \\
\hline 9 & 20 & 30 & 0.3 & 40.15 & 35.73 \\
\hline 10 & 20 & 26 & 0.5 & 43.14 & 34.19 \\
\hline 11 & 20 & 28 & 0.5 & 44.69 & 33.82 \\
\hline 12 & 20 & 30 & 0.5 & 42.05 & 39.33 \\
\hline C. No & $\begin{array}{l}\text { Viscosity } \\
\left(\mathrm{ml} \cdot \mathrm{g}^{-1}\right)\end{array}$ & $\begin{array}{c}\text { Breaking } \\
\text { Length }(\mathrm{km})\end{array}$ & $\begin{array}{c}\text { Tear } \\
\text { index } \\
\left(\mathrm{mN} \cdot \mathrm{m}^{2} \cdot \mathrm{g}^{-1}\right)\end{array}$ & $\begin{array}{c}\text { Burst } \\
\text { index } \\
\left(\mathrm{kPa} \cdot \mathrm{m}^{2} \cdot \mathrm{g}^{-1}\right)\end{array}$ & $\begin{array}{c}\text { Brightness } \\
\text { (\%ISO) }\end{array}$ \\
\hline 1 & 1060 & 3.77 & 2.98 & 1.90 & 18.98 \\
\hline 2 & 1008 & 3.73 & 2.95 & 1.83 & 19.09 \\
\hline 3 & 1075 & 3.89 & 2.37 & 1.73 & 18.85 \\
\hline 4 & 1005 & 3.66 & 1.28 & 1.48 & 20.93 \\
\hline 5 & 1168 & 3.13 & 1.93 & 1.38 & 21.89 \\
\hline 6 & 1098 & 3.90 & 1.61 & 1.50 & 20.52 \\
\hline 7 & 1110 & 4.04 & 1.76 & 1.69 & 21.47 \\
\hline 8 & 1106 & 3.39 & 1.56 & 1.39 & 20.91 \\
\hline 9 & 1077 & 3.23 & 1.35 & 1.35 & 20.27 \\
\hline 10 & 1141 & 3.13 & 1.62 & 1.42 & 22.74 \\
\hline 11 & 1079 & 2.80 & 1.52 & 1.09 & 21.69 \\
\hline 12 & 1042 & 3.68 & 1.09 & 1.57 & 20.52 \\
\hline
\end{tabular}

The pulp yield, kappa number and viscosity value of canola stalks were

presented in Table 4 with those of some other annual plants.

Table 4. Pulp properties of canola stalks and some annual plants

\begin{tabular}{|c|c|c|c|c|}
\hline Literature & $\begin{array}{l}\text { Cooking } \\
\text { Method }\end{array}$ & $\begin{array}{c}\text { Total Yield } \\
(\%)\end{array}$ & $\begin{array}{l}\text { Kappa } \\
\text { Number }\end{array}$ & 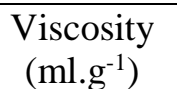 \\
\hline Canola stalks (current study) & Kraft-NaBH 4 & 44.69 & 33.82 & 1079 \\
\hline Cotton stalks (Tutus et al., 2010) & Kraft-NaBH 4 & 44.30 & 33.42 & 1045 \\
\hline Wheat stalk (Tutus, 2000) & Soda & 50.46 & 18.10 & 686 \\
\hline $\begin{array}{l}\text { Hordeum vulgare (Pahkala, } \\
\text { 2001) }\end{array}$ & Soda-AQ & 48.30 & 19.90 & - \\
\hline Avena sativa (Pahkala, 2001) & Soda-AQ & 42.30 & 14.40 & 1180 \\
\hline Secale cereale (Pahkala, 2001) & Soda-AQ & 48.20 & 12.50 & 1100 \\
\hline $\begin{array}{l}\text { Table } 4 \text { indicates that the pulp } \\
\text { obtained from the canola stalk } \\
\text { accordance with the literature. } \\
\text { The end groups of carbohy } \\
\text { protected from peeling reactions } \\
\mathrm{NaBH}_{4} \text { as a catalyst in cooking } \\
\text { (Istek and Ozkan } 2008 \text {; Tutus \& } \\
\text { 2016). Since NaBH} \text { S }_{4} \text { reduces th } \\
\text { reactions during cooking, the } \\
\text { increased. With using NaBH } \\
\text { liquor, the total yield has increa }\end{array}$ & $\begin{array}{l}\text { broperties } \\
\text { were in } \\
\text { rates are } \\
\text { by using } \\
\text { processes } \\
\text { Cicekler, } \\
\text { peeling } \\
\text { ield has } \\
\text { cooking }\end{array}$ & \multicolumn{3}{|c|}{$\begin{array}{l}8.7 \% \text { and kappa numbers and viscosity } \\
\text { values have decreased. Besides, screen reject } \\
\text { has also increased from } 1.15 \% \text { to } 2.03 \% \text {. } \\
\text { Kappa number indicates the pulp } \\
\text { bleachability and it is generally used to } \\
\text { determination lignin content of pulp. The } \\
\text { kappa number decreased by approximately } \\
9.7 \% \text { with the addition of } \mathrm{NaBH}_{4} \text { to the } \\
\text { cooking liquor when compared with } 2^{\text {nd }} \text { and } \\
11^{\text {th }} \text { trials. These decreases in kappa number } \\
\text { indicate that the lignin content of the pulps is } \\
\text { low and it can be easily bleached. Hart and }\end{array}$} \\
\hline
\end{tabular}


Connell (2006) reported that bleachability tends to decrease as the kappa number increases.

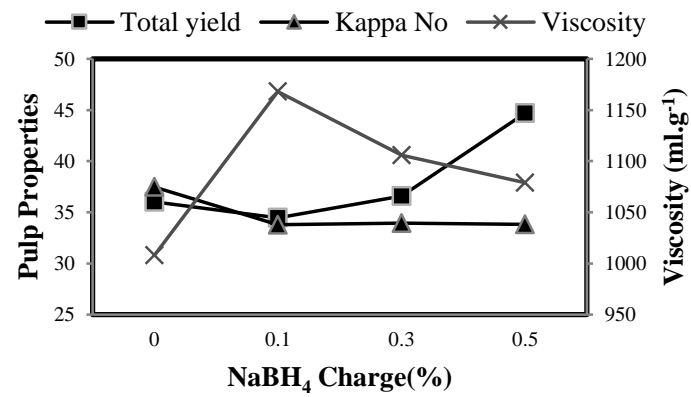

Figure 1. Effects of $\mathrm{NaBH}_{4}$ on canola pulp properties (sulfidity: 28\%, active alkali: 20\%)

Viscosity is generally used to investigate degree of chemical damage to fibers or degree of polymerization of cellulose chain in fibers. In this study, viscosity value of the pulp obtained $11^{\text {th }}$ trial was higher than that of $2^{\text {nd }}$ trial about $6.6 \%$.

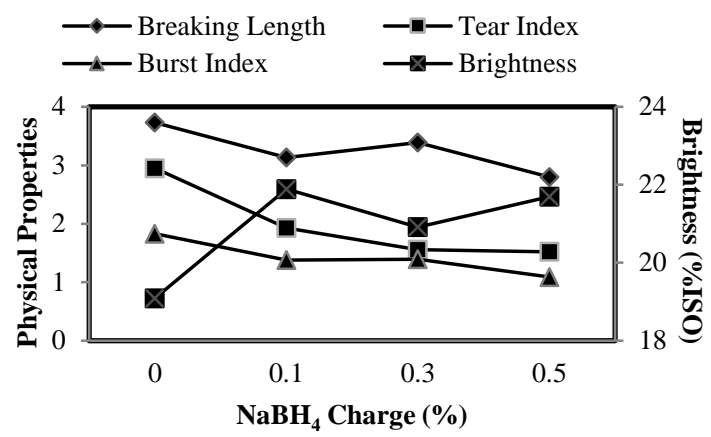

Figure 2. Effects of $\mathrm{NaBH}_{4}$ on physical and optical properties (sulfidity: 30\%, active alkali: 20\%)
In addition, $\mathrm{NaBH}_{4}$ is also used in pulp bleaching as a bleaching agent (Tutus \& Usta, 2004; Okan et al., 2013). The brightness value of the pulp obtained by adding $\mathrm{NaBH}_{4}$ to the cooking liquor has increased about $13.6 \%\left(2^{\text {nd }}\right.$ and $11^{\text {th }}$ trails $)$. In a study, Akgul and Temiz (2006) have used $\mathrm{NaBH}_{4}$ in pulp production from Uludag Fir. They found that the brightness values of pulps have increased by using $\mathrm{NaBH}_{4}$. However, the physical properties of the papers have decreased (Fig. 2). Many studies have reported that $\mathrm{NaBH}_{4}$ is used to improve the bleaching performance and obtain highbrightness pulps (Sjöström and Eriksson, 1968; Ni, Sommerville \& van Heiningen, 2001; Wang, Li, Ni \& Zhang, 2004; Dang, Elder \& Regauskas, 2007; Saracbasi, Sahin \& Karademir, 2016).

To clearly understand the effect of $\mathrm{NaBH}_{4}$ on the pulp and paper properties, the sulfidity charge $(28 \%)$ and the active alkali charge (20\%) were kept constant and the $\mathrm{NaBH}_{4}$ charge was changed to $0,0.1,0.3$ and 0.5 . Then, variance analysis and Duncan test were performed on obtained data and presented in Table 5.

Table 5. Effects of $\mathrm{NaBH}_{4}$ on pulp and paper properties

\begin{tabular}{lcccc}
\hline C. No & $\mathrm{NaBH}_{4}(\%)$ & Total yield $(\%)$ & $\begin{array}{c}\text { Kappa } \\
\text { No }\end{array}$ & $\begin{array}{c}\text { Viscosity } \\
\left(\mathrm{ml}^{-g^{-1}}\right)\end{array}$ \\
\hline 2 & & $36.01 \mathrm{~b}$ & $37.47 \mathrm{~b}$ & $1008 \mathrm{c}$ \\
5 & 0 & $34.46 \mathrm{c}$ & $33.79 \mathrm{a}$ & $1168 \mathrm{a}$ \\
8 & 0.1 & $36.59 \mathrm{~b}$ & $33.95 \mathrm{a}$ & $1106 \mathrm{~b}$ \\
11 & 0.3 & $44.69 \mathrm{a}$ & $33.82 \mathrm{a}$ & $1079 \mathrm{a}$ \\
\hline Sig. & 0.5 & .023 & .047 & .004 \\
\hline C. No & - & Tear & Burst & Brightness \\
\hline 2 & $(\mathrm{~km})$ & index $\left(\mathrm{mN} \cdot \mathrm{m}^{2} . \mathrm{g}^{-1}\right)$ & index $\left(\mathrm{kPa} \cdot \mathrm{m}^{2} . \mathrm{g}^{-1}\right)$ & $(\%$ ISO) \\
\hline 5 & $3.73 \mathrm{a}$ & $2.95 \mathrm{a}$ & $1.83 \mathrm{a}$ & $19.09 \mathrm{~b}$ \\
8 & $3.13 \mathrm{~b}$ & $1.93 \mathrm{~b}$ & $1.38 \mathrm{~b}$ & $21.89 \mathrm{a}$ \\
11 & $3.39 \mathrm{a}$ & $1.56 \mathrm{c}$ & $1.39 \mathrm{~b}$ & $20.91 \mathrm{~b}$ \\
Sig. & $2.80 \mathrm{~b}$ & $1.52 \mathrm{c}$ & $1.09 \mathrm{c}$ & $21.69 \mathrm{a}$ \\
\hline
\end{tabular}

According to the results of the variance analysis, it is seen in Table 5 that the $\mathrm{NaBH}_{4}$. charge has a significant effect on all pulp and paper properties. Mean values with the same 
lower-case letters are not significantly different at $95 \%$ confidence level according to Duncan's mean separation test. it can easily be understood that the pulp and paper characteristics, especially total yield and brightness values were changed by the addition of $\mathrm{NaBH}_{4}$ to the cooking liquor.

\section{Conclusions}

The paper industry is in a serious strait due to the lack of wood raw materials. Therefore, the evaluation of agricultural wastes as an important cellulose sources will play an important role for solving this problem. As a result of this study, it has been determined that canola stalks can be used as an alternative non-wood raw material for pulp and paper industry. The holocellulose and alpha cellulose content of the canola stalks is within acceptable limit for pulp and paper production.

Many methods are being developed to increase the yield in pulp production. In this study, $\mathrm{NaBH}_{4}$ was found to be effective on the yield by adding it to the cooking solution. It increased the pulp yield about $24.1 \%\left(2^{\text {nd }}\right.$ and $11^{\text {th }}$ trials). Besides, it also improved the pulp brightness value about $13.6 \%$. Parallel to this, it also reduced the kappa number and facilitated the bleaching of pulp.

Evaluation of generally burned or disposed canola stalks in pulp and paper production would be an important contribution to the country economy such as Turkey, where wood resources are limited.

\section{References}

Akgul, M. (2007). Determination of the pulp and paper production conditions with sodaalcohol, soda-AQ, soda-alcohol-AQ methods from cotton straw (Gossypium hirsutum L.). Presidency of Scientific Research Projects, SRP Project Code (2005.05), 03.221.

Akgul, M. \& Temiz, S. (2006). Determination of Kraft-NaBH 4 pulping condition of Uludag Fir (Abies Bornmuelleriana Mattf.). Pakistan Journal of Biological Sciences, 9 (13), 24932497.

Ashori, A. (2006). Nonwood fibers-A potential source of raw material in papermaking. Polymer-Plastics Technology and Engineering, 10 (1), 1133-1136.

Baunelos, G. S., Bryla, D. R. \& Cook, C. G. (2002). Vegetative production of kenaf and canola under irrigation in Central California. Industrial Crops and Products, 15 (1), 237245.
Courchene, C. E. (1998). The tired, the true and the new-getting more pulp from chips-modifications to the kraft process for increased yield. Proceeding of: Breaking the Pulp Yield Barrier Symposium, Tappi Press, Atlanta: 11-20 .

Dang, Z., Elder, T. \& Regauskas, A.J. (2007). Alkaline peroxide treatment of ECF bleached softwood kraft pulps. Part 1. Characterizing the effect of alkaline peroxide treatment on carboxyl groups of fibers. Holzforschung, 61 (1), 445-450.

Deniz, I., Okan, O. T., Serdar, B. \& Şahin, H. I. (2017). Kraft and modified kraft pulping of bamboo (Phyllostachys bambusoides). Drewno, 60(200), 79:94.

Ekhtera, M. H., Azadfallah, M., Bahrami, M. \& Rovshandeh, J. M. (2009). Comparative study of pulp and paper properties of canola stalks prepared by using dimethyl formamide or diethylene glycol. Bioresources, 4(1), 214233.

Enayati, A. A., Hamzeh, Y., Mirshokraie, S.A. \& Molaii, M. (2009). Papermaking potential of canola stalks. Bioresources, 4 (1), 245-256.

Eroglu, H. (1987). Soda-oxygen anthraquinone pulping of wheat straw. Nonwood Plant Fiber Pulping Progress Report, No. 17, Houston.

Eroglu, H., Usta, M. \& Kirci, H. (1992). A Review of oxygen pulping conditions of some non-wood plant growing in Turkey. Tappi Pulping Conference Proceeding, 215-222.

Eroğlu, H. \& Deniz, İ. (1998). $\mathrm{O}_{2}-\mathrm{NaOH}$ pulping of predesilicated wheat straw (Triticum aestivum L.). Inpaper International., 2(5), 1420.

Faostat, 2018. Food and Agriculture Organization of the United Nations website, http://www.fao.org/faostat/en/\#data/QC: 27.11.2018.

Gencer, A., Eroglu, H. \& Deniz, I. (2005). The effects of oxygen and air to pulp production from wheat straw using $\mathrm{KOH}$ agent. International Journal of Bartin Faculty of Forestry, 77 (1), 9-13.

Guler, M., Kara, T. \& Dok, M. (2005). Using geographic information systems (GIS) techniques to determine potential rapeseed (Brassica napus L.) production area in Middle Black Sea Region. Journal of Agricultural Faculty of Ondokuz Mayıs University, 20 (1), 44-49.

Gunduz, G., Asik, A., Aydemir, D. \& Kilic, A. (2015). The production and characterization of bacterial cellulose. Duzce University Journal of Forestry, 10 (12), 1-10.

Hafizoğlu, H. \& Deniz, İ. (2007). Wood Chemistry Lecture Notes. Karadeniz Technical University, Forest Faculty Publication, Trabzon-Turkey. 
Hart, P. \& Connell, D. (2006). The Effect of Digester Kappa on the Bleachability and Yield of EMCCTM Softwood Kraft Pulp. Tappi Journal, 5(5), 23-27.

Hosseinpour, R. \& Latibari, A. J. (2012). The Papermaking potential of canola residues; viable raw material. Proceedings of the $55^{\text {th }}$ International Convention of Society of Wood Science and Technology, Beijing, China .

Istek, O. \& Ozkan, I. (2008). Effect of sodium borohydride on Populus tremula L. Kraft Pulping. Turkish Journal of Agriculture and Forestry, 32(2), 131-136.

Istek A. \& Gonteki, E. (2009). Utilization of sodium borohydride $\left(\mathrm{NaBH}_{4}\right)$ in kraft pulpingprocess. Journal of Environmental Biology, 30(6), 5-6.

Kirci, H. (2006). Pulp Industry Lecture Notes. Karadeniz Technical University, Forest Faculty Publication, Trabzon-Turkey.

Kiaei, M., Mahdavi, S., Kialashaki, A., Nemati, M., Samariha, A. \& Saghafi, A. (2014). Chemical composition and morphological properties of canola plant and its potential application in pulp and paper industry. Cellulose Chemistry and Technology, 48(1-2), 105-110.

Mohammad, M., Enayati, A. A., Hamzeh, Y. \& Roustaei, M. (2010). Preparation of bleached soda pulp from canola stalks. Iranian Journal of Wood and Paper Science Research, 25(1), 80-90.

Moon, R. J., Martini, A., Nairn, J., Simonsenf, J. \& Youngblood, J. (2011). Cellulose nanomaterials review: structure, properties and nanocomposites. Chemical Society Reviews, 40 (1), 3941-3994.

Ni, Y., Sommerville, J. \& van Heiningen, A.R.P. (2001). Bleaching of recycled fibers by adding sodium borohydride to a peroxide reinforced oxygen stage. Tappi Journal, 84(6), 67.

Okan, O. T., Deniz, İ. \& Yildirim, İ. (2013). Bleaching of bamboo (Phyllostachys Bambusoides) Kraft-AQ pulp with dodium perborate tetrahydrate (SPBTH) after oxygen delignification. Bioresources, 8(1), 13321344.

Pahkala, S. K. (2001). Nonwood Plants as Raw Material for Pulp and Paper. Agriculture and Food Science Finland, 10, 1-101.

Potucek, F., Gurung, B. \& Hajkova, K. (2014). Soda pulping of rapeseed straw. Cellulose Chemistry and Technology, 48(7-8), 683-691.

Rousu, P., Rousis, P. \& Anttila, J. (2002). Sustainable pulp production from agricultural waste. Resources, Conservation and Recycling, 35, 85-103.

Rowell, R. M., Young, R. A. \& Rowell, J. K. (1997). Paper and composites from agrobased resources. CRC press, USA.
Saracbasi, A., Sahin, H. T. \& Karademir, A. (2016). A. Effects of sodium borohydride addition to kraft pulping process of some pine species. Journal of Forestry Research, 2, 134143.

Sarwar, J. M., Nasima, C. D. A. \& Khalidul, I. M. (2006). Characterization and evaluation of golpata fronds as pulping raw materials. Bioresource Technology, 97, 401-406.

Shatalov, A. A. \& Pereira, H. (2006). Papermaking fibers from giant reed (Arundo donax L.) by advanced ecologically friendly pulping and bleaching technologies. Bioresources, 1: 45-61.

Sjöström, E. \& Eriksson, E. (1968). The influence of carboxyl and carbonyl groups on the brightness stability of bleached pulps. Tappi Journal, 51, 16-19.

SKSV, (2018). Turkey Cellulose and Paper Industry Foundation, Annual Sector Reports.

Tiras, M. (2009). Agriculture of Canola in Turkey. Eastern Geographical Review, 14(21), 159-172.

Tran, A. V. (2006). Chemical analysis and pulping study of pineapple crown leaves. Industrial Crops and Products, 24, 66-74.

Tutus, A. (2000). The investigation of sodaoxygen, soda-anthraquinone and soda methods used in pulp production from wheat (Triticum aestivum L.) straw on the problem of silica and other aspects. $\mathrm{Ph}$. D. dissertation, Institute of Science, Zonguldak Karaelmas University, Bartın, Turkey.

Tutus, A., Cicekler, M. \& Karatas, B. (2011). Pulp and paper production by Kraft-Sodium Borohydride method from Poppy Stems. II. International Non-Wood Forest Products Symposium, Isparta, 183-190.

Tutus, A., Cicekler, M., Ozdemir, A. \& Altas, A. (2014). Evaluation of Astragalus membranaceus in pulp and paper production. III. International Non-Wood Forest Products Symposium, Kahramanmaras, 323-331.

Tutus, A. \& Eroglu, H. (2003). A practical solution to silica problem in straw pulping. Appita Journal, 56(2), 111-115.

Tutus, A. \& Eroglu, H. (2004). An alternative solution to the silica problem in wheat strawpulping. APPITA Journal, 57(3), 214217.

Tutus, A., Ezici, A. C. \& Ates, S. (2010). Chemical, morphological and anatomical properties and evaluation of cotton stalks (Gossypium hirsutum L.) in pulp industry. Scientific Research and Essays, 5(12), 15531560.

Tutus, A., Kazaskeroglu, Y. \& Cicekler, M. (2015). Evaluation of tea wastes in usage pulp and paper production. Bioresources, 10(3), 5407-5416. 
Tutus, A. \& Cicekler, M. (2016). Evaluation of common wheat stubbles (triticum aestivum L.) for pulp and paper production. Drvna Industrija, 67(3), 271-279 .

Tutus, A. \& Usta, M. (2004). Bleaching of chemithermomechanical pulp (CTMP) using environmentally friendly chemicals. Journal of Environmental Biology, 25(2), 141-146.

Wang, S., Li, Z., Ni, Y. \& Zhang, E. (2004). Sodium borohydride assisted hydrogen peroxide bleaching process for mechanical pulps. Appita Journal, 57, 377-380.

Wanrosli, W. D., Zainuddin, Z., Lawb, K. N. \& Asro, R. (2007). Pulp from oil palm fronds by chemical processes. Industrial Crops and Products, 25, 89-94.

Wise, L.E. \& Murphy, M. (1946). A chlorite holocellulose, its fractionation and bearing on summative wood analysis and studies on hemicelluloses. Paper Trade Journal, 122, 35-43.

Zawawi, D., Mohd, Z. M. H., Angzzas, S. M. K., Halizah, A. \& Ashuvila, M. A. (2014). Exploring of agro waste (pineapple leaf, corn stalk and napier grass) by chemical component and morphological study. Bioresources, 9(1), 872-880.

ISO 2470-1:2016 Paper, board and pulpsMeasurement of diffuse blue reflectance
factor-Part 1: Indoor daylight conditions (ISO brightness).

ISO 5269-2:2004 Pulps-Preparation of laboratory sheets for physical testing-Part 2: RapidKöthen method,

TAPPI T203 cm-09:2009 Alpha, beta and gamma-cellulose in pulp.

TAPPI T204 cm-07:2007 Solvent extractives of wood and pulp.

TAPPI T207 cm-08:2008 Water solubility of wood and pulp.

TAPPI T211 om-02:2002 Ash in wood, pulp, paper and paperboard: combustion at $525^{\circ} \mathrm{C}$.

TAPPI T212 om-12:2012 One percent sodium hydroxide solubility.

TAPPI T222 om-11:2011 Acid-insoluble lignin in wood and pulp.

TAPPI T230 om-08:2008 Viscosity of pulp (capillary viscometer method).

TAPPI T236 om-99:1999 Kappa number of pulp.

TAPPI T403 om-15:2015 Bursting strength of paper.

TAPPI T414 om-88:1988 Internal tearing resistance of paper (Elmendorf-type method).

TAPPI T494 om-06:2006 Tensile properties of paper and paperboard. 